\title{
REPEATABILITY ESTIMATES AND MINIMUM NUMBER OF EVALUATIONS FOR SELECTION OF ELEPHANT-GRASS GENOTYPES FOR FORAGE PRODUCTION
}

\author{
ESTIMATIVAS DE REPETIBILIDADE E NÚMERO MÍNIMO DE AVALIAÇÕES \\ PARA SELEÇÃO DE GENÓTIPOS DE CAPIM-ELEFANTE PARA PRODUÇÃO DE \\ FORRAGEM
}

\author{
Erina Vitório RODRIGUES ${ }^{1^{*}}$; Rogério Figueiredo DAHER ${ }^{2}$; \\ Geraldo de Amaral GRAVINA ${ }^{2}$; Alexandre Pio VIANA ${ }^{3}$; \\ Maria do Socorro Bezerra de ARAÚJO' ${ }^{2}$; Maria Lorraine Fonseca OLIVEIRA ${ }^{2}$; \\ Marcelo VIVAS ${ }^{2}$; Bruna Rafaela da Silva MENEZES ${ }^{2}$; \\ Antônio Vander PEREIRA ${ }^{4}$
}

1. Universidade de Brasília, Campus Planaltina, DF, Brasil. erinavict@hotmail.com; 2. Laboratório de Engenharia Agrícola - Centro de Ciências e Tecnologias Agropecuárias, Universidade Estadual do Norte Fluminense Darcy Ribeiro, Campos dos Goytacazes, RJ, Brasil; 3. Laboratório de Melhoramento Genético Vegetal - Centro de Ciências e Tecnologias Agropecuárias, Universidade Estadual do Norte Fluminense Darcy Ribeiro, Campos dos Goytacazes, RJ, Brasil; 4. Embrapa Gado de Leite, Juiz de Fora, MG, Brasil Brasil.

\begin{abstract}
In forage-plants breeding, the selection of superior genotypes has been undertaken through successive harvests in previously established intervals. However, this process involves many steps, the evaluation of many traits, and a great spending with costs and labor. Thus the estimate of the repeatability is essential in improvement of perennials, it allows predicting genotypic value of the individual, the minimum number of evaluations in the selection of genotypes and minimizes resources and time in the selection of promising individuals. The objective of this study was to estimate the repeatability coefficient for morphological traits in elephant grass and determine the number of evaluations needed for phenotypic selection more efficient. The experimental randomized block design with 53 genotypes and two replications. The repeatability coefficients were estimated for variables plant height, number of tillers, stem diameter and dry matter yield, using the methods of Anova, Principal Components and Structural Analysis. We observed significant differences between genotypes $(\mathrm{P}<0.01)$ for all variables. The main components provide larger estimates of repeatability when compared to other methods. Estimates of the repeatability coefficients are of high magnitude average for the variables plant height (0.44) number of tillers $(0.44)$ and stem diameter $(0.63)$ and low magnitude for dry matter production $(0.27)$. The Principal Components method requires five, five, two and eleven measurements for plant height, number of tillers, stem diameter and dry matter yield, respectively, with $80 \%$ reliability.
\end{abstract}

KEYWORDS: Pennisetum purpureum S. Coefficient of determination. Main components. Dry matter yield.

\section{INTRODUCTION}

Tropical forage plants have a great importance in the Brazilian agricultural scenario, as they constitute the main feeding source for dairy and meat herds. In this regard, the elephant grass (Pennisetum purpureum Schum) stands out for its high herbage production (PEGORARO et al., 2009), as a species of high dry matter yield (7.3 - $14.5 \mathrm{t} \mathrm{ha}^{-}$ $\left.{ }^{1}\right)$ potential and high crude protein value (919.4 $1591.0 \mathrm{~kg} \mathrm{ha}^{-1}$ ) that adapts easily to adverse soilclimatic conditions (LIMA et al., 2007; PACIULLO et al., 2008; LIMA et al., 2011). These features make the elephant grass a highly promising crop in the animal production chain.
In forage-plants breeding, the selection of superior genotypes has been undertaken through successive harvests in previously established intervals. However, this process involves many steps, the evaluation of many traits, and a great spending with costs and labor (OLIVEIRA et al., 2011). An alternative to minimize these challenges is the use of repeatability. By the estimate of the repeatability coefficient (r), it is possible to determine how many evaluations should be performed until the phenotypic evaluation shows high efficiency (CRUZ et al., 2012).

The repeatability coefficient is defined statistically as the correlation between the measurements made in the same individual, whose 
evaluations have been repeated in time or space (LUSH, 1964; ABEYWARDENA, 1972; KEMPTHORNE, 1973). Repeatability expresses the proportion of the total variance of a trait that is explained by the genotypes and by permanent alterations attributed to the common environment (CRUZ et al., 2012). This parameter is of great importance in the prediction of genetic and genotypic values, and in the inference on the increase in selective efficiency by using a given number of evaluations per individual, a factor that makes it possible to determine the number of harvests to be adopted in a genetic breeding program (VIANA; RESENDE, 2014).

When several measurements are made in the same individuals and the most promising ones are identified, these individuals are expected to sustain good performance in future evaluations. However, according to Cruz et al. (2012), the veracity of this expectation can also be validated through the repeatability coefficient of the studied trait. These authors also stressed that repeatability varies according to the nature of the trait, with the genetic properties of the population, and with the environment conditions under which individuals are maintained.

It is essential to utilize methodologies that maximize efficiency in the phenotypic selection and that minimize the costs with financial and human resources. Several authors have obtained the estimate of the repeatability coefficient in many forage species, such as Pennisetum purpureum (DAHER et al., 2004; VIANA et al., 2009;
OLIVEIRA et al., 2011; CAVALCANTE et al., 2012), Panicum maximum (MARTUSCELLO et al., 2007; LÉDO et al., 2008), Brachiaria brizantha (MARTUSCELLO et al., 2013), Medicago sativa (FREITAS et al., 2011), and also other perennial cultures like sugarcane (FERREIRA et al., 2005), coffee (CECON et al., 2008), banana (LESSA et al., 2014), and guaraná (NASCIMENTO FILHO et al., 2009).

Given the above scenario, the objective of this study was to obtain estimates of the repeatability coefficient for morpho-agronomic traits in elephant grass and to determine the number of necessary evaluations for greater efficiency in the phenotypic selection.

\section{MATERIAL AND METHODS}

The experiment was conducted at the State Center for Research on Bioenergy and Waste Use at the experimental station of PESAGRO-RIO, located in Campos dos Goytacazes, RJ, Brazil (21 ${ }^{\circ} 45^{\prime} 15^{\prime \prime} \mathrm{S}$ latitude and $41^{\circ} 19^{\prime} 28^{\prime \prime} \mathrm{W}$ longitude; $13 \mathrm{~m}$ altitude). The place is situated in a mild topography area, on a soil classified as dystrophic Argisol. The classification, the climate in the region is a tropical hot and wet Aw type, dry in the winter and rainy in the summer. The average annual precipitation is around 1,023 mm (MENDONÇA et al., 2007). The precipitation occurring during the experiment was measured at the Evapotranspiration Station Irrigation and Agrometeorology Section, at UENF/PESAGRO (Figure 1).

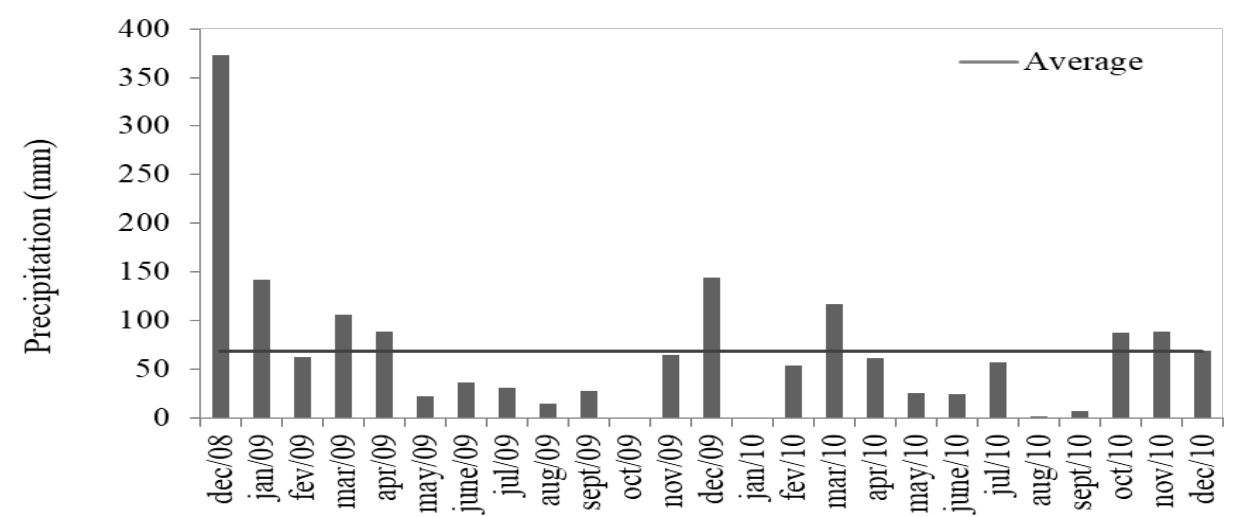

Figure 1. Precipitation occurred during the elephant grass experiments.

Fifty-three genotypes of elephant grass (Table 1) were arranged in a randomized blocks design with two replicates. The plot consisted of two $3-\mathrm{m}$ rows spaced $0.5 \mathrm{~m}$ apart, with $3.0 \mathrm{~m}$ between plots. Seeding was carried out 04/25/2008. Soil preparation consisted of disc harrowing and leveling harrowing. The plot-leveling cut was made on $10 / 03 / 2008$, and the harvests for evaluations occurred on $02 / 04 / 2009,04 / 14 / 2009,07 / 18 / 2009$, 10/15/2009, 12/15/2009, 03/08/2010, 05/12/2010, $09 / 17 / 2010$, and $12 / 03 / 2010$. Fertilization was applied based on the soil analysis and according to the recommendations for the plant (LIRA et al., 2010). 
Table 1. Identification of 53 genotypes of collection of job germplasm bank of elephant grass of UENF, used in the study of repeatability.

\begin{tabular}{|c|c|c|c|c|c|}
\hline $\mathrm{N}^{\mathrm{o}}$ & Genotype & Procedence & $\mathrm{N}^{\mathrm{o}}$ & Genotype & Origin \\
\hline 1 & Elefante da Colômbia & Colômbia & 28 & Mole de Volta Grande & Volta Grande - SP \\
\hline 2 & Mercker & IPEACO - MG & 29 & Porto Rico & CAMIG \\
\hline 3 & Três Rios & Nova Odessa - SP & 30 & Napier & Pedro Leopoldo - MG \\
\hline 4 & Napier Volta Grande & UFRRJ - Km 47 & 31 & Merckeron Comum & Pindamonhangada - SP \\
\hline 5 & Mercker Santa Rita & UFRRJ - Km 47 & 32 & Terezópolis & UFRRJ - Km 47 \\
\hline 6 & Pusa Napier $n^{\circ} 2$ & Índia & 33 & Taiwan A-26 & UFRRJ - Km 47 \\
\hline 7 & Gigante de Pinda & Pindamonhangaba - SP & 34 & Duro de Volta Grande & UFRRJ - Km 47 \\
\hline 8 & Napier Goiano & Goiás & 35 & Mercker C. de Pinda & UFRRJ - Km 47 \\
\hline 9 & MerckerS.E.A. & UFRRJ - Km 47 & 36 & Turrialba & UFRRJ - Km 47 \\
\hline 10 & Taiwan A-148 & UFRRJ - Km 47 & 37 & Taiwan A-146 & UFRRJ - Km 47 \\
\hline 11 & Porto Rico 534-B & UFV - Viçosa - MG & 38 & Cameroon - Piracicaba & UFRRJ - Km 47 \\
\hline 12 & Taiwan A-25 & UFRRJ - Km 47 & 39 & Taiwan A-121 & UFRRJ - Km 47 \\
\hline 13 & Albano & Colômbia & 40 & Vrukwona & Piracicaba - SP \\
\hline 14 & Híbrido G. Colômbia & Colômbia & 41 & T241-Piracicaba & CNPGL \\
\hline 15 & Pusa Gigante Napier & Índia & 42 & IAC - Campinas & UFRRJ - Km 47 \\
\hline 16 & Elefante Híbrido 534-A & UFV - Viçosa - MG & 43 & Elefante C. de tapemirim & UFRRJ - Km 47 \\
\hline 17 & Costa Rica & Turrialba & 44 & Capim-Cana D'África & EMCAPA - ES \\
\hline 18 & Cubano de Pinda & UFRRJ - Km 47 & 45 & Gramafante & - \\
\hline 19 & Merckeron de Pinda & UFRRJ - Km 47 & 46 & Roxo & ESAL - Lavras - MG \\
\hline 20 & Merckeron P. México & UFRRJ - Km 47 & 47 & Guaçu/IZ.2 & Nova Odessa - SP \\
\hline 21 & Mercker 86 México & Colômbia & 48 & Cuba-116 & Embrapa Gado de Leite \\
\hline 22 & Taiwan A-144 & UFRRJ - Km 47 & 49 & King Grass & Embrapa Gado de Leite \\
\hline 23 & Napier S.E.A. & UFRRJ - Km 47 & 50 & Vruckwona Africano & Embrapa Gado de Leite \\
\hline 24 & Taiwan A-143 & UFRRJ - Km 47 & 51 & Cameroon & Embrapa Gado de Leite \\
\hline 25 & Pusa Napier $n^{\circ} 1$ & UFRRJ - Km 47 & 52 & IJ $7141 \mathrm{cv}$ EMPASC 306 & Embrapa Gado de Leite \\
\hline 26 & Elefante de Pinda & Colômbia & 53 & Pasto Panamá & Embrapa Gado de Leite \\
\hline 27 & Mineiro & UFV-Viçosa & & & \\
\hline
\end{tabular}

The evaluated variables were plant height $(\mathrm{PH})$, in meters, obtained using a measuring tape, measured from the soil to the point of inflection of the last fully expanded leaf; number of tillers (NT), by counting the number of tillers in the useful area; stem diameter (SD), in millimeters, measured $10 \mathrm{~cm}$ above the soil using a digital caliper; and dry matter yield (DMY), in $\mathrm{tha}^{-1}$, by weighing the plants in the useful area of the plot, collecting a sample that was conditioned in a paper bag, weighed, and dried in an oven at $65^{\circ} \mathrm{C}$ for $72 \mathrm{~h}$. These samples were weighed again to determine the air-dried sample (ADS). Subsequently, this material was ground through a 1 $\mathrm{mm}$ sieve and dried in an oven at $105{ }^{\circ} \mathrm{C}$ for $12 \mathrm{~h}$ to determine the oven-dried sample (ODS). Based on the ADS and ODS values, the percentage of dry matter was obtained and DMY was estimated.

An analysis of variance was run for the variables analyzed in each cut (environment). The homogeneity of the residual variances was tested by the ratio between the highest and lowest residual mean square (RMS), considering seven as the threshold to meet this assumption, as described by Pimentel-Gomes and Garcia (2002). It was found that this assumption was not met, and a discrepancy was observed in the RMS of environment five $(12 / 15 / 2009)$, which made it impossible to include the nine environments in the combined analysis. 
Thus, environment five was eliminated, and the variances showed homogeneity, which enabled the combined analysis, considering the following model:

$$
\begin{aligned}
Y_{i j k}= & m+G_{i}+B_{k}+A_{j}+G A_{i j}+e_{i j k}, \\
& \text { where } Y_{i j k}=\text { effect of genotype } \mathrm{i} \text { in }
\end{aligned}
$$

environment $\mathrm{j}$, in block $\mathrm{k} ; \mathrm{m}=$ overall constant; $\mathrm{G}_{\mathrm{i}}=$ fixed effect of genotype $i(i=1,2, \ldots, 53) ; A_{j}=$ random effect of environment $\mathrm{j}(\mathrm{j}=1,2,3, \ldots, 8), \mathrm{A}_{\mathrm{j}} \sim$ $\operatorname{NID}\left(0, \sigma^{2}\right) ; \mathrm{GA}_{\mathrm{ij}}=$ effect of the interaction between genotype $\mathrm{i}$ and environment $\mathrm{j}$; and $e_{\mathrm{ijk}}=$ effect of the experimental error associated with observation $Y_{i j k}$, $e_{i j k} \sim \operatorname{NID}\left(0, \sigma^{2}\right)$.

The repeatability coefficient was estimated by four distinct statistical procedures: Analysis of Variance; Principal Components (based on covariance and correlation matrices); and Structural Analysis (based on the correlation matrix).

The following statistical model was used to estimate the repeatability coefficient by the Analysis of Variance (ANOVA) method:

$Y_{i j}=m+g_{i}+a_{j}+e_{i j}$,

where $\mathrm{m}=$ overall constant; $\mathrm{g}_{\mathrm{i}}=$ random effect of group i under influence of the permanent environment $(i=1,2,3, \ldots, 53), g_{i} \sim \operatorname{NID}\left(0, \sigma^{2}\right) ; a_{j}=$ fixed effect of the temporary environment in the $j$-th measurement $(j=1,2,3, \ldots, 8)$; and $\mathrm{e}_{\mathrm{ij}}=$ experimental error of the effects of temporary environment associated with the $\mathrm{j}$-th measurement in genotype $\mathrm{i}$, $\mathrm{e}_{\mathrm{ij}} \sim$ NID $\left(0, \sigma^{2}\right)$. Thus, the repeatability coefficient is given by:

$$
\hat{r}=\operatorname{cov}\left(Y_{i j}, Y_{i j^{\prime}}\right) / \sqrt{V\left(Y_{i j}\right) V\left(Y_{i j^{\prime}}\right)}=\frac{\hat{\sigma}_{g}^{2}}{\hat{\sigma}^{2}+\hat{\sigma}_{g}^{2}}
$$

where, $\hat{\sigma}_{g}^{2}$ is the variance attributed to the genotype effect, and $\hat{\sigma}^{2}$ is the residual variance.

The Principal Components methodology, utilized by Abeywardena (1972), allows us to estimate the coefficient of repeatability in two ways, by the correlation matrix and by the covariance matrix between genotypes, obtained in each pair of measurements. Thus, they efficiently provide estimates for situations in which the evaluated genotypes display a cyclic behavior in relation to the studied traits.

When based on the correlation matrix, the normalized eigenvalues $(\lambda)$ and eigenvectors $(\alpha)$ of $\mathrm{R}$ are determined. The eigenvector whose elements show the same sign and close magnitudes is that which expresses the trend of genotypes to maintain their relative positions in the many harvest intervals. Based on this eigenvalue, the repeatability coefficient is estimated (RUTLEDGE, 1974): $\hat{r}=\left(\lambda_{1}-1\right) /(\eta-1)$

where, $\lambda_{1}=$ eigenvalue obtained in matrix $\hat{R}$, associated with the eigenvector, whose elements had the same sign and similar magnitudes; and $\eta=$ number of measurements $(\eta=8)$.

When based on the covariance matrix, the repeatability coefficient was estimated considering the parametric matrix of phenotypic variances and covariance $(\Gamma)$ :

$r=\left(\hat{\lambda}_{1}-\hat{\sigma}_{Y}^{2}\right) /\left[\hat{\sigma}_{Y}^{2}(\eta-1)\right]$

where, $\hat{\sigma}_{Y}^{2}=\sigma^{2}+\sigma_{g}^{2}$ is the variance of

variable $\mathrm{Y}$ and $\eta$ is the number of measurements.

The Structural Analysis method to obtain the repeatability coefficient proposed by Mansour et al. (1981) shows some conceptual differences compared with the Principal Components method. In this method, $\mathrm{R}$ is considered the parametric correlation matrix between the genotypes in each evaluation pair, and $\widehat{R}$ is its estimator. Thus, the estimator of the repeatability coefficient was given by:

$\hat{r}=\left(a^{\prime} \hat{R} a-1\right) /(n-1)$

where: $a^{\prime}=$ eigenvector with parametric elements associated with the highest $\mathrm{R}$ eigenvalue; $\mathrm{R}=$ parametric correlation matrix between genotypes in each evaluation pair; $\bar{R}=$ estimator of matrix $R$; and $\eta=$ number of measurements.

The minimum number of measurements necessary to predict the real value of the individuals, based on a pre-established coefficient of determination $\left(\mathrm{R}^{2}\right)(0.80,0.85,0.90$, and 0.95$)$, was predicted based on the following expression:

$\eta_{0}=R^{2}(1-\hat{r}) /\left(1-R^{2}\right) r$

where, $\eta_{0}=$ number of measurements for the prediction of the real value; $r=$ repeatability coefficient obtained according to one of the different methods utilized.

Phenotypic stabilization was evaluated by using the Principal Components methods, obtained from the correlation matrix of the successive measurements, considering all evaluations performed. All statistical analyses were carried out using the GENES software (CRUZ, 2013).

\section{RESULTS AND DISCUSSION}

Significant differences were detected between the genotypes $(p<0.01)$ for all evaluated variables, demonstrating the existence of variability, which provides a successful selection of promising genotypes (Table 2). The effects of the genotypes $\times$ 
environment interaction were significant $(\mathrm{p}<0.01)$ for the variables plant height and stem diameter. The significant interaction means that the response of the genotypes was not coincident in the different environments. This result is explained by the fact that the evaluations were performed over a long period, considering the soil-climatic variations, especially precipitation, which was highly irregular (Figure 1). This emphasizes the importance of studying repeatability aiming to determine the number of minimum measurements to predict the real value of genotypes.

Table 2. Summary of analysis of variance for the variables plant height $(\mathrm{PH})$, stem diameter (ST), number of tillers (SD) and dry matter yield (DMY) in elephant grass genotypes.

\begin{tabular}{|c|c|c|c|c|c|}
\hline \multirow{2}{*}{ Source de Variation } & \multicolumn{3}{|c|}{ MS } & \multirow[b]{2}{*}{ DS } & \multirow[b]{2}{*}{ DMY } \\
\hline & GL & PH & NT & & \\
\hline Blocks & 1 & 0.0203 & 43.0290 & 1216.6600 & 10.3821 \\
\hline Genotypes (G) & 52 & $0.1814 * *$ & $28.7614 * *$ & $1195.0244 * *$ & $13.2057 * *$ \\
\hline Environment (E) & 7 & $4.2024 * *$ & $400.6018 * *$ & $3282.1325 * *$ & $272.7545 * *$ \\
\hline Genotypes x Environment (GxE) & 364 & $0.0299 * *$ & $4.4799 * *$ & $93.0879^{\mathrm{ns}}$ & $3.9526^{\mathrm{ns}}$ \\
\hline Residue & 423 & 0.0194 & 2.9165 & 117.6456 & 3.4194 \\
\hline Average & - & 1.74 & 12.87 & 39.3 & 6.34 \\
\hline $\mathrm{CV}_{\mathrm{e}}(\%)$ & - & 7.97 & 13.26 & 27.59 & 29.15 \\
\hline Higher RMS/smallerRMS & - & 3.51 & 5.25 & 3.79 & 3.89 \\
\hline
\end{tabular}

** and ns: significant at $5 \%$ and not significant by the $\mathrm{F}$ test

The experiment had good precision (PIMENTEL-GOMES; GARCIA 2002), given that $\mathrm{CV}_{\mathrm{e}}$ ranged from 7.97 to $29.15 \%$ for plant height and dry matter productivity, respectively, contributing to increasing the reliability of the estimates and of the results obtained in this study. Daher et al. (2004) estimated genetic parameters and repeatability coefficients in elephant grass for the same variables presented in this study, and found $\mathrm{CV}_{\mathrm{e}}$ varying from 9.23 to $46.78 \%$ for stem diameter and dry matter yield, respectively. The authors stress that the environmental control should be increased aiming to minimize the influence of the environment in the genotype discrimination process.

The study of repeatability is essential in plant breeding, as it expresses the proportion of total variance explained by the variations caused by the genotype and by the permanent changes, attributed to a common environment (ABEYWARDENA, 1972; CRUZ et al., 2012). The magnitude of the estimates of the repeatability coefficients varied between 0.23 for dry matter yield, by ANOVA, and 0.62 for number of tillers, by Principal Components based on the covariance matrix (Table 3 ).

Table 3. Estimates of the repeatability coefficient $(r)$ and their coefficients of determination $\left(R^{2}\right)$ for plant height variables $(\mathrm{PH})$, stem diameter (SD), number of tillers (NT) and dry matter yield (DMY) in elephant grass genotypes obtained by different methods of estimation.

\begin{tabular}{|c|c|c|c|c|c|c|c|c|c|}
\hline \multirow{3}{*}{\multicolumn{2}{|c|}{ Methodologys }} & \multicolumn{8}{|c|}{ Variables } \\
\hline & & \multicolumn{2}{|l|}{$\mathrm{PH}$} & \multicolumn{2}{|l|}{ NT } & \multicolumn{2}{|c|}{ SD } & \multicolumn{2}{|c|}{ DMY } \\
\hline & & $\mathrm{r}$ & $\mathrm{R}^{2}(\%)$ & $\mathrm{r}$ & $\mathrm{R}^{2}(\%)$ & $\mathrm{r}$ & $\mathrm{R}^{2}(\%)$ & $\mathrm{r}$ & $\mathrm{R}^{2}(\%)$ \\
\hline \multicolumn{2}{|c|}{ Analysis of Variance } & 0.39 & 83.51 & 0.40 & 84.42 & 0.60 & 92.21 & 0.23 & 70.07 \\
\hline $\begin{array}{l}\text { Principal } \\
\text { (covariace) }\end{array}$ & Components & 0.44 & 86.04 & 0.44 & 86.04 & 0.63 & 93.05 & 0.27 & 74.58 \\
\hline $\begin{array}{l}\text { Principal } \\
\text { (correlation) }\end{array}$ & Components & 0.42 & 85.19 & 0.41 & 84.70 & 0.62 & 92.79 & 0.28 & 75.99 \\
\hline Structural An & lysis & 0.40 & 84.47 & 0.40 & 84.42 & 0.62 & 92.75 & 0.27 & 74.34 \\
\hline
\end{tabular}

The repeatability-coefficient estimate for dry matter yield showed low magnitude. This suggests that there was no regularity in the repetition of the performance of the genotype from one evaluation to another, which is corroborated by the genotypes $\times$ environments interaction. These low values can be explained by the occurrence of several factors, like influence of the soil-climatic conditions. The variation in rainfall is a noteworthy factor, as it contributes to seasonality, to the 
experimental control, and to the random errors inherent to the quantification of this variable, since the measurement of DMY involves the relationship among three variables: green mass, air-dried mass, and oven-dried mass.

Estimating repeatability for forage traits in Panicum maximum genotypes, Lédo et al. (2008) also found $r$ estimates with similar magnitudes to those presented in this study for the variable dry matter yield, which varied from 0.23 and 0.35 . However, working with Pennisetum purpureum, Cavalcante et al. (2012) obtained high-magnitude repeatability estimates $(r>0.80)$ for the same variable, irrespective of the estimation method. These higher values may be attributed to experimental-control factors like the use of a larger number of replicates, which reinforces the great influence of environmental conditions in these estimates. Furthermore, the authors reported that all variables had been adjusted by the variance matrix, allowing for higher repeatability estimates.

The repeatability coefficient estimates for the variable plant height were considered of medium magnitude $(0.39<\mathrm{r}<0.44)$. Similar results were reported by Martuscello et al. (2015), estimating repeatability in Panicum maximum genotypes. According to these authors, this variable is important in the evaluation of forage plants, as it correlates with biomass production and may have specific recommendations according to the desired use, be it in the feeding of grazing animals like goat and sheep, or even for use in cattle feeding.

The variable number of tillers stood out, with high-magnitude estimates for the repeatability coefficient $(\mathrm{r}>0.6)$ and high coefficients of determination $\left(\mathrm{R}^{2}>90 \%\right)$. Assuming that the response of genotypes over the successive harvests was maintained, this was expected, since no significant effect of the source of variation genotypes $\times$ environment was detected for this variable. High repeatability coefficients are desired, because when a promising genotype is selected, this superiority is expected to last throughout its entire life cycle, and the speed of this expectation is corroborated by the repeatability coefficient (CRUZ et al, 2012); as the repeatability coefficient is increased, the number of repeated measures necessary to predict the real value of the individual is reduced. However, because these are quantitative variables of a perennial species, the magnitude of these estimates may be considered sufficient, since the coefficient of determination $\left(\mathrm{R}^{2}\right)$, which expresses the accuracy of prediction of the real value of the individual, was higher than $70 \%$.

In general, the different methods to estimate the repeatability coefficients agreed with each other, and the $r$ estimates for the four variables, obtained by the principal components method, were always higher compared with the ANOVA based method. Abeywardena (1972) state that the Principal Components method provides a more efficient estimate of the repeatability coefficient in situations in which the genotypes show a cyclic response in relation to the studied trait, because it is based on the covariance matrix between genotypes obtained in each pair of measurements.

The superiority of the repeatabilitycoefficient estimates obtained by the Principal Components method based on the covariance matrix have been reported in many forage species: Penissetum purpureum (CAVALCANTE et al., 2012); Panicum maximum (MARTUSCELLO et al., 2007; LÉDO et al., 2008); Brachiaria brizantha (MARTUSCELLO et al., 2013), as well as in fruits, like banana (LESSA et al., 2014).

The method to estimate the repeatability coefficient based on ANOVA provides lower $r$ estimates, because this method does not isolate the periodicity factor, which, when occurs, is included in the experimental error $\left(\sigma^{2}\right)$, which increases its value and generates a repeatability underestimate (VASCONCELLOS et al., 1985). In general, the repeatability-coefficient estimates were of medium to high magnitude for most variables, and indicate reliability in the identification of superior genotypes.

Because of the large expenditure of resources and the time employed in each cycle of evaluation of the perennial crops to achieve consistent results, it is necessary to estimate the number of evaluations required for selection of promising genotypes. This is possible by the previous establishment of the desired accuracy. Therefore, the number of measurements necessary to characterize the studied variables, with $80 \%$ reliability, for prediction of the real value of the individual, was of at least 2 for the number of tillers by the Principal Component analysis, and 14 for dry matter yield by ANOVA (Table 4). An increase in the accuracy to predict the real value of the measurements, in all methods utilized, implied an increase in the number of measurements, but would not do much for precision. 
Table 4. Number of necessary evaluations for different coefficients of determination $\left(\mathrm{R}^{2}\right)$ for the variables plant height $(\mathrm{PH})$, stem diameter (SD), number of tillers (NT) and dry matter production (DMY) in genotypes elephant grass, obtained by different methods of estimation.

\begin{tabular}{|c|c|c|c|c|c|}
\hline \multirow{2}{*}{ Methodologies } & \multirow{2}{*}{$\mathrm{R}^{2}(\%)$} & \multicolumn{4}{|c|}{ Variables } \\
\hline & & $\mathrm{PH}$ & SD & NT & DMY \\
\hline \multirow{4}{*}{ Analysis of Variance } & 80 & 6 & 6 & 3 & 14 \\
\hline & 85 & 9 & 8 & 4 & 19 \\
\hline & 90 & 14 & 13 & 6 & 31 \\
\hline & 95 & 30 & 28 & 13 & 65 \\
\hline \multirow{4}{*}{ Principal Components (covariance) } & 80 & 5 & 5 & 2 & 11 \\
\hline & 85 & 7 & 7 & 3 & 15 \\
\hline & 90 & 12 & 12 & 5 & 25 \\
\hline & 95 & 25 & 25 & 11 & 52 \\
\hline \multirow{4}{*}{ Principal Components (correlation) } & 80 & 6 & 5 & 2 & 10 \\
\hline & 85 & 8 & 8 & 4 & 14 \\
\hline & 90 & 13 & 12 & 6 & 23 \\
\hline & 95 & 26 & 26 & 12 & 48 \\
\hline \multirow{4}{*}{ Structural Analysis } & 80 & 6 & 6 & 3 & 11 \\
\hline & 85 & 8 & 8 & 4 & 16 \\
\hline & 90 & 13 & 13 & 6 & 25 \\
\hline & 95 & 28 & 27 & 12 & 52 \\
\hline
\end{tabular}

Corroborating this information, we observe that, in order to increase accuracy from 85 to $90 \%$, almost twice the number of measurements would be necessary, irrespective of the variable and method utilized. In practice, this is unfeasible, as it would be costly and time-consuming. These results agree with those obtained by Basso et al (2009), who, estimating genetic parameters and the minimum number of measurements necessary for the selection of Brachiaria brizantha genotypes, observed that six measurements provided $80 \%$ reliability. To reach $90 \%$, it would be necessary to add eight measurements for the variable leaf dry matter.

By the ANOVA method, 14 measurements would be necessary for the variable dry matter yield, whereas by the Principal Components method based on the correlation matrix, only 10 measurements would be required, with $80 \%$ reliability. Disagreeing with these results, Daher et al. (2004) reported that five measurements were sufficient to predict the real value of elephant grass genotypes with $90 \%$ reliability by the Principal Components method based on the covariance matrix. Souza Sobrinho et al. (2010), in contrast, evaluated repeatability in Urochloa ruziziensis and found that it required 32 observations. These results allow us to infer that these estimates vary both in the same species and in different species.

As regards the variable number of tillers, at least six harvests would be necessary, with $90 \%$ reliability, regardless of the method utilized. The number of evaluations performed in this study was then sufficient to estimate the real value of the individual for the variables plant height, stem diameter, and number of tillers with $85 \%$ reliability, irrespective of the method adopted. However, for the variable dry matter yield, the number of evaluations performed was insufficient. This can be justified, since, according to Heinemann et al. (2005), dry matter yield is influenced by climatic variables, especially temperature and precipitation.

It is considered that selection based on these four traits is sufficient in the initial stage of selection. Thus, the resources employed with a large number of assessments can be invested in the subsequent stages of the breeding process, in which the number of genotypes is reduced and experimental precision is increased, e.g., by an increase in the number of replicates. Although the lower number of measurements spares financial resource and increases the speed of the selection process, it is important to consider the fact that a sufficient number of measurements is necessary so as to evaluate the production stability, especially when working with perennial plants, which are deeply affected by the environment, because they remain for a longer period in the field.

It is crucial that repeatability-coefficient estimates be obtained in stabilized genotypes. If the genotype in which the estimate of repeatability is 
obtained is not stabilized, the variance within individuals will include a considerable part of the variance of the interaction of the genotype with the effects of temporary environment. Moreover, the increase in the number of measurements aimed at reducing variation within individuals might not be advantageous, since the additional variance caused by the interaction may be sufficient to offset the reduction of the component (CRUZ et al., 2012).

The variable plant height showed a mediummagnitude $r$ estimate when harvests three and four were correlated $(\mathrm{r}=0.61)$, and low-magnitude for the correlation between harvests five and six $(\mathrm{r}=0.04)$ (Table 5). These values are possibly explained by the uniformity in age between this pair of harvests, because the time interval was the same in their period of assessment, whereas between harvests five and six the time interval was discrepant in relation to the others, due to the need for excluding the harvest that caused heterogeneity of the variances. Additionally, the low values may be associated with the period of harvest with occurrence of lower rainfall, because precipitation during the period of harvests five and six was $116.9 \mathrm{~mm}$ and $25.9 \mathrm{~mm}$, respectively.
The highest $r$ estimate was found for the variable number of tillers $(\mathrm{r}=0.78)$ when harvests one and two were correlated, indicating stabilization of the genotypes for this variable. It should be stressed that, for this variable, the genotypes did not interact with the environment, resulting in their performance being maintained throughout the evaluations.

For the variables stem diameter and dry matter yield, the pair of harvests seven and eight showed coincidence, culminating in lower $r$ estimates, indicating that the genotypes were not stabilized for these traits. When the measured genotype is not stabilized, the variation in the individuals will contain a fraction of the variance of the genotype with temporary environment, and an increment in the number of measurements would not be beneficial (MARTUSCELLO et al., 2015). Overall, the highest repeatability estimates for the variable dry matter yield were obtained when harvest four was correlated with the others, whereas the lowest estimates were observed with the inclusion of harvests one and two.

Table 5. Numbers measurements $(\eta)$ and obtaining the coefficient of determination $\left(R^{2}\right)$ by means of stabilizing genotype using the method of principal components from the correlation matrix (cp) for plant height $(\mathrm{PH})$, stem diameter (SD), number of tillers (NT) and dry matter yield (DMY) in elephant grass genotypes in eight successive evaluations

\begin{tabular}{|c|c|c|c|c|c|c|c|c|c|c|c|c|c|c|}
\hline \multicolumn{3}{|c|}{ Evaluation } & \multicolumn{3}{|c|}{$\begin{array}{l}\text { Plant } \\
\text { height }\end{array}$} & \multicolumn{3}{|c|}{$\begin{array}{l}\text { Stem } \\
\text { diameter }\end{array}$} & \multicolumn{2}{|c|}{$\begin{array}{l}\text { Number } \\
\text { of tillers }\end{array}$} & \multicolumn{4}{|c|}{$\begin{array}{l}\text { Dry matter } \\
\text { Yield }\end{array}$} \\
\hline & & & $\eta$ & $\mathrm{r}(\mathrm{cp})$ & $\mathrm{R}^{2}(\%)$ & $\eta$ & $\mathrm{r}(\mathrm{cp})$ & $\mathrm{R}^{2}(\%)$ & $\eta$ & $\mathrm{r}(\mathrm{cp})$ & $\mathrm{R}^{2}(\%)$ & $\eta$ & $\mathrm{r}(\mathrm{cp})$ & $\mathrm{R}^{2}(\%)$ \\
\hline 1 & - & 2 & 2 & 0.50 & 66.51 & 2 & 0.78 & 87.74 & 2 & 0.70 & 82.44 & 2 & 0.38 & 55.18 \\
\hline 1 & - & 3 & 3 & 0.51 & 75.91 & 3 & 0.41 & 67.49 & 3 & 0.66 & 85.11 & 3 & 0.24 & 48.16 \\
\hline 1 & - & 4 & 4 & 0.51 & 80.56 & 4 & 0.43 & 74.93 & 4 & 0.61 & 86.39 & 4 & 0.23 & 54.30 \\
\hline 1 & - & 5 & 5 & 0.49 & 82.57 & 5 & 0.43 & 78.91 & 5 & 0.60 & 88.09 & 5 & 0.29 & 67.11 \\
\hline 1 & - & 6 & 6 & 0.41 & 80.57 & 6 & 0.45 & 83.28 & 6 & 0.62 & 90.85 & 6 & 0.28 & 69.53 \\
\hline 1 & - & 7 & 7 & 0.43 & 84.12 & 7 & 0.41 & 83.11 & 7 & 0.61 & 91.77 & 7 & 0.31 & 75.74 \\
\hline 1 & - & 8 & 8 & 0.42 & 85.19 & 8 & 0.42 & 85.44 & 8 & 0.62 & 92.79 & 8 & 0.28 & 75.99 \\
\hline 2 & - & 3 & 2 & 0.49 & 65.55 & 2 & 0.18 & 30.76 & 2 & 0.69 & 81.58 & 2 & 0.17 & 28.99 \\
\hline 2 & - & 4 & 3 & 0.56 & 79.11 & 3 & 0.43 & 69.14 & 3 & 0.63 & 83.38 & 3 & 0.26 & 51.34 \\
\hline 2 & - & 5 & 4 & 0.48 & 78.44 & 4 & 0.37 & 69.92 & 4 & 0.62 & 86.68 & 4 & 0.34 & 67.43 \\
\hline 2 & - & 6 & 5 & 0.39 & 75.86 & 5 & 0.42 & 78.48 & 5 & 0.64 & 89.92 & 5 & 0.32 & 69.86 \\
\hline 2 & - & 7 & 6 & 0.44 & 82.40 & 6 & 0.40 & 80.22 & 6 & 0.63 & 91.11 & 6 & 0.35 & 76.73 \\
\hline 2 & - & 8 & 7 & 0.43 & 83.81 & 7 & 0.41 & 82.68 & 7 & 0.63 & 92.34 & 7 & 0.31 & 76.24 \\
\hline 3 & - & 4 & 2 & 0.61 & 75.55 & 2 & 0.51 & 67.71 & 2 & 0.61 & 75.76 & 2 & 0.37 & 53.71 \\
\hline 3 & - & 5 & 3 & 0.50 & 74.94 & 3 & 0.30 & 55.77 & 3 & 0.62 & 83.08 & 3 & 0.46 & 71.97 \\
\hline 3 & - & 6 & 4 & 0.34 & 67.69 & 4 & 0.36 & 69.14 & 4 & 0.63 & 87.14 & 4 & 0.39 & 72.07 \\
\hline
\end{tabular}




\begin{tabular}{|c|c|c|c|c|c|c|c|c|c|c|c|c|c|c|}
\hline 3 & - & 7 & 5 & 0.41 & 77.94 & 5 & 0.39 & 76.23 & 5 & 0.63 & 89.54 & 5 & 0.43 & 79.12 \\
\hline 3 & - & 8 & 6 & 0.41 & 80.53 & 6 & 0.38 & 78.43 & 6 & 0.63 & 91.01 & 6 & 0.36 & 77.41 \\
\hline 4 & - & 5 & 2 & 0.35 & 52.32 & 2 & 0.28 & 43.37 & 2 & 0.71 & 83.26 & 2 & 0.54 & 70.41 \\
\hline 4 & - & 6 & 3 & 0.22 & 45.26 & 3 & 0.39 & 65.97 & 3 & 0.67 & 85.96 & 3 & 0.42 & 68.83 \\
\hline 4 & - & 7 & 4 & 0.36 & 69.27 & 4 & 0.35 & 68.50 & 4 & 0.66 & 88.37 & 4 & 0.46 & 77.60 \\
\hline 4 & - & 8 & 5 & 0.39 & 76.53 & 5 & 0.37 & 74.76 & 5 & 0.63 & 89.59 & 5 & 0.38 & 75.70 \\
\hline 5 & - & 6 & 2 & 0.04 & 7.99 & 2 & 0.38 & 54.73 & 2 & 0.68 & 81.15 & 2 & 0.42 & 59.22 \\
\hline 5 & - & 7 & 3 & 0.22 & 45.62 & 3 & 0.24 & 48.03 & 3 & 0.63 & 83.39 & 3 & 0.49 & 73.96 \\
\hline 5 & - & 8 & 4 & 0.33 & 66.80 & 4 & 0.34 & 66.94 & 4 & 0.62 & 86.63 & 4 & 0.39 & 72.02 \\
\hline 6 & - & 7 & 2 & 0.35 & 51.85 & 2 & 0.32 & 48.77 & 2 & 0.63 & 77.08 & 2 & 0.44 & 61.19 \\
\hline 6 & - & 8 & 3 & 0.41 & 67.48 & 3 & 0.32 & 58.83 & 3 & 0.63 & 83.38 & 3 & 0.33 & 59.84 \\
\hline 7 & - & 8 & 2 & 0.56 & 71.61 & 2 & 0.15 & 25.93 & 2 & 0.56 & 71.70 & 2 & 0.16 & 27.36 \\
\hline
\end{tabular}

\section{CONCLUSIONS}

The repeatability-coefficient estimates are of medium to high magnitude, for the variables plant height (0.44), number of tillers (0.44), and stem diameter (0.63), and of low magnitude for dry matter yield (0.27) in elephant grass.
The Principal Components approach provides higher repeatability estimates compared with the other methods.

Five, five, two, and eleven evaluations are required to predict the variables plant height, number of tillers, stem diameter, and dry matter yield, respectively, with $80 \%$ reliability by the Principal Components method based on the covariance matrix.

RESUMO. No melhoramento de plantas forrageiras, a seleção de genótipos superiores tem sido realizada mediante a realização de cortes sucessivos em intervalos previamente estabelecidos. Entretanto este processo envolve muitas etapas, avaliação de muitos caracteres e um grande dispêndio de custos e mão-deobra. Assim, a estimativa da repetibilidade é essencial no melhoramento de plantas perenes, pois permite predizer o valor genotípico do indivíduo, o número mínimo de avaliações na seleção de genótipos e minimiza recursos e tempo na seleção de indivíduos promissores. $\mathrm{O}$ objetivo deste trabalho foi obter estimativas do coeficiente de repetibilidade para caracteres morfoagronômicos em capim-elefante e determinar o número de avaliações necessárias para seleção fenotípica com maior eficiência. Utilizou-se delineamento experimental de blocos casualizados com 53 genótipos e duas repetições. Foram estimados os coeficientes de repetibilidade para as variáveis altura de plantas (ALT), número de perfilhos (NP), diâmetro de colmo (DC) e produtividade de matéria seca (PMS), utilizando-se os métodos da Anova, Componentes principais e Análise estrutural. Observaram-se diferenças significativas entre os genótipos $(\mathrm{p}<0,01)$ para todas as variáveis avaliadas. Os componentes principais proporcionam maiores estimativas de repetibilidade em relação aos demais métodos. As estimativas dos coeficientes de repetibilidade são de média a alta magnitude, para as variáveis ALT, NP e DC e de baixa magnitude para PMS. Com base no método dos Componentes Principais são necessárias cinco, cinco, duas e onze medidas para altura da planta, número de perfilhos, diâmetro do caule e rendimento de matéria seca, respectivamente, com $80 \%$ de confiabilidade.

PALAVRAS-CHAVE: Pennisetum purpureum S. Coeficiente de determinação. Produtividade de matéria seca.

\section{REFERENCES}

ABEYWARDENA, V. An application of principal component analysis in genetics. Journal of Genetics, India, v. 61, n. 1, p. 27-51, 1972. Disponível em: https://link.springer.com/article/10.1007/BF02984099 https://doi.org/10.1007/BF02984099 
BASSO, K. C.; RESENDE, R. M. S.; DO VALLE, C. B.; GONÇALVES, M. C.; LEMPP, B. Avaliação de acessos de Brachiaria brizantha Stapf e estimativas de parâmetros genéticos para caracteres agronômicos. Acta Scientiarum Agronomy, Maringá, v. 31, n. 1, p. 17-22, 2009. Disponível em: http://dx.doi.org/10.4025/actasciagron.v31i1.6605

CAVALCANTE, M.; LIRA, M. A.; DOS SANTOS, M. V. F.; PITA, E. B. A. F.; FERREIRA, R. L. C.; TABOSA, J. N. Coeficiente de repetibilidade e parâmetros genéticos em Capim-elefante. Pesquisa Agropecuária Brasileira, Brasília, v. 47, n. 4, p. 569-575, 2012. Disponível em: http://dx.doi.org/10.1590/S0100-204X2012000400013

CECON, P. R.; SILVA, F. F.; FERREIRA, A.; FERRÃO, R. G.; SOUZA CARNEIRO, A. P.; DETMANN, E.; FARIA, P. N.; MORAIS, T. S. S. Análise de medidas repetidas na avaliação de clones de café 'Conilon'. Pesquisa Agropecuária Brasileira, Brasília, v. 43, n. 9, p. 1171-1176, 2008. Disponível em: http://dx.doi.org/10.1590/S0100-204X2008000900011

CRUZ, C. D.; REGAZZI, A. J.; CARNEIRO, P. C. S. Modelos biométricos aplicados ao melhoramento genético. 4. ed. Viçosa: UFV, 2012. 514 p.

CRUZ, C. D. (2013). GENES - a software package for analysis in experimental statistics and quantitative genetics. Acta Scientiarum Agronomy, Maringá, v. 35, n. 3, p. 271-276, 2013. Disponível em: https://dx.doi.org/10.4025/actasciagron.v35i3.21251

DAHER, R. F.; MALDONADO, H.; PEREIRA, A. V.; DO AMARAL JUNIOR, A. T.; PEREIRA, M. G.; FERREIRA, C. F.; RAMOS, S. R. R.;TARDIM, F. D.; DA SILVA, M. P. Estimativas de parâmetros genéticos e de coeficientes de repetibilidade de caracteres forrageiros em clones de capim-elefante (Pennisetum purpureum Schum.). Acta Scientiarum Agronomy, Maringá, v. 26, n. 4, p. 483-490, 2004. Disponível em: http://dx.doi.org/10.4025/actasciagron.v26i4.1823

FERREIRA, A.; BARBOSA, M. H. P.; CRUZ, C. D.; HOFFMANN, H. P.; VIEIRA, M. A. S.; BASSINELLO, A. I.; SILVA, M. D. Repetibilidade e número de colheitas para seleção de clones de cana-de-açúcar. Pesquisa Agropecuária Brasileira, Brasília, v. 40, n. 8, p. 761-767, 2005. Disponível em: http://dx.doi.org/10.1590/S0100-204X2005000800005

FREITAS, A. R.; DE PAULA, R.; MOREIRA, A. Análises de dados de medidas repetidas por meio do modelo linear geral e do modelo misto. Revista Ciência Agrárias, Amazonia, v. 54, n. 3, p. 214-224, 2011. Disponível em: http://periodicos.ufra.edu.br/index.php/ajaes/article/view/307 https://doi.org/10.4322/rca.2012.017

HEINEMANN, A. B.; FONTES, A. J.; PACIULLO, D. S. C.; ROSA, B.; MACEDO, R.; MOREIRA, P.; AROEIRA, L. J. M. Potencial produtivo e composição bromatológica de seis gramíneas forrageiras tropicais sob duas doses de nitrogênio e potássio. Pasturas Tropicales, Cali, v. 27, n. 1, p. 34-41, 2005. Disponível em: http://tropicalgrasslands.info/public/journals/4/Elements/DOCUMENTS/2005-vol27-rev1-23/Vol_27_rev1_05_pags_34-41.pdf

KEMPTHORNE, O. The design and analysis of experiments. New York: Robert E. Krieger Publishing Company. 1973. $631 \mathrm{p}$.

LÉDO, F. J. D. S.; PEREIRA, A. V.; SOUZA SOBRINHO, F. D.; AUAD, A. M.; JANK, L., OLIVEIRA, J. S. Estimativas de repetibilidade para caracteres forrageiros em Panicum maximum. Ciência Agrotecnica, Lavras, v. 32, n. 4, p. 1299-1303, 2008. Disponível em: https://dx.doi.org/10.1590/S1413-70542008000400040

LESSA, L. S.; LEDO, C. A. S.; AMORIM, E. P.; DE OLIVEIRA, S. (2014). Estimativas de repetibilidade de híbridos diploides (AA) de bananeira. Pesquisa Agropecuária Brasileira, Brasília, v. 49, n. 2, p. 109-117, 2014. Disponível em: https://dx.doi.org/10.1590/S0100-204X2014000200005 
LIMA, E. S.; SILVA, J. F. C.; VASQUEZ, H. M. Produção de material seca e proteína bruta e relação folha/colmo de genótipos de capim-elefante aos 56 dias de rebrota. Revista Brasileira de Zootecnia, Viçosa, v. 36, n. 5, p. 1518-1523, 2007. Disponível em: https://dx.doi.org/10.1590/S1516-35982007000700009

LIMA, R. S. N.; DAHER, R. F.; GONÇALVES, L. S. A.; ROSSIi, D. A.; AMARAL JÚNIOR, A. T.; PEREIRA, M. G.; LÉDO, F. J. S. RAPD and ISSR markers in the evaluation of genetic divergence among accessions of elephant grass. Genetics and Molecular Research, Ribeirão Preto, v. 10, n. 3, p. 1304-1313, 2011. Disponível em: 10.4238/vol10-3gmr1107 https://doi.org/10.4238/vol10-3gmr1107

LIRA, M. A.; SANTOS M.; DUBEUX JÚNIOR J. C.; MELLO A.; Capim elefante: fundamentos e perspectivas. Recife: IPA/UFRPE, 2010. 229p.

LUSH, J. L. Melhoramento dos animais domésticos. Tradução de CARNEIRO, G. G.; MEMORIA, J. M. P.; DRUNMOND, G. Rio de Janeiro: CEDEGRA. 1964. 570 p.

MANSOUR, H.; NORDHEIM, E. V.; RUTLEDGE, J.J. Estimators of repeatability. Theoretical and Applied Genetics, Berlin, v. 60, n. 3, p. 151-156, 1981. Disponível em: https://doi.org/10.1007/BF00264520

MARTUSCELLO, J. A., JANK, L.; FONSECA, D. M. D.; CRUZ, C. D.; CUNHA, D. D. N. F. V. Agronomic characters repeatability in Panicum maximum Jacq. Revista Brasileira de Zootecnia, Viçosa, v. 36, n. 6, p. 1975-1981, 2007. Disponível em: https://dx.doi.org/10.1590/S1516-35982007000900005

MARTUSCELLO, J. A.; BRAZ, T. G. D. S.; JANK, L.; CUNHA, D. D. N. F. V.; SOUZA, M. W. M.; BRITO, G. F. D.; OLIVEIRA, L. P. D. Repeatability of agronomic characters in Brachiaria brizantha cultivars. Revista Brasileira de Zootecnia, Viçosa, v. 42, n. 1, p. 30-35, 2013. Disponível em: https://dx.doi.org/10.1590/S151635982013000100005

MARTUSCELLO, J. A.; BRAZ, T. G. D. S.; JANK, L.; CUNHA, D. D. N. F. V.; LIMA, B. P. D. S.; OLIVEIRA, L. P. D. Repeatability and phenotypic stabilization of Panicum maximum accessions. Acta Scientiarum Animal Sciences, Maringá, v. 37, n. 1, p. 15-21, 2015. Disponível em: https://dx.doi.org/10.4025/actascianimsci.v37i1.23206

MENDONÇA, J. C.; SOUZA, E. F.; BERNARDO, S.; SUGAWARA, M. T.; PEÇANHA, A. L.; GOTTARDO, R. D. Determinação do coeficiente cultural (Kc) do feijoeiro (Phaseolus vulgaris L.) em Campos dos Goytacazes, RJ. Revista Brasileira de Engenharia Agrícola e Ambiental, Campina Grande, v. 5, n. 11, p. 471-475, 2007. Disponível em: https://dx.doi.org/10.1590/S1415-43662007000500004

NASCIMENTO FILHO, F. J.; ATROCH, A. L.; CRUZ, C. D.; CARNEIRO, P. C. S. Repetibilidade da produção de sementes em clones de guaraná. Pesquisa Agropecuária Brasileira, Brasília, v. 44, n. 6, p. 605612, 2009. Disponível em: https://dx.doi.org/10.1590/S0100-204X2009000600009

OLIVEIRA, T. N.; SANTOS, M. V. F.; LIRA, M. A.; MELLO, A. C. L.; LIRA JÚNIOR, M. A.; SILVA, N. G. M. Estimativa de repetibilidade para mancha ocular em clones de Pennisetum. Arquivos de Zootecnia, Córdoba, v. 60, n. 231, p. 797-808, 2011. Disponível em: https://dx.doi.org/10.4321/S000405922011000300067

PACIULLO, D. S. C.; CAMPOS, N. R.; GOMIDE, C. A. M.; CASTRO, C. R. T.; TAVELA, R. C.; ROSSIELLO, C. A. M. Crescimento de capim-braquiária influenciado pelo grau de sombreamento e pela estação do ano. Pesquisa Agropecuária Brasileira, Brasília, v. 43, n. 7, p. 917-923, 2008. Disponível em: https://dx.doi.org/10.1590/S0100-204X2008000700017

PEGORARO, R. F.; MISTURA, C.; WENDLING, B.; FONSECA, D. M.; FAGUNDES, J. L. Manejo da água e do nitrogênio em cultivo de capim elefante. Ciência Agrotécnica, Lavras, v. 33, n. 2, p. 461-467, 2009. Disponível em: https://dx.doi.org/10.1590/S1413-70542009000200015 
PIMENTEL-GOMES, F.; GARCIA, C. H Estatística aplicada a experimentos agronômicos e florestais: exposição com exemplos e orientações para uso de aplicativos, Piracicaba: FEALQ. 2002. 309p.

RUTLEDGE, J.J. A scaling which removes bias of Abeywardena's estimator of repeatability. Journal of Genetics, Bangalore, v. 61, n. 3, p. 247-250, 1974. Disponível em: https://doi.org/10.1007/BF02986435

SOUZA SOBRINHO, F.; BORGES, V.; LÉDO, F. J. D. S.; KOPP, M. M. Agronomic traits repeatability and number of cuts needed for selecting Urochloa ruziziensis. Pesquisa Agropecuária Brasileira, Brasília, v. 45, n. 6, p. 579-584, 2010. Acessível em: https://dx.doi.org/10.1590/S0100-204X2010000600007

VASCONCELLOS, M. E.; GONÇALVES, P. S.; DE PAIVA, J. R.; VALOIS, A. C. C. Métodos de estimação do coeficiente de repetibilidade no melhoramento da seringueira. Pesquisa Agropecuária Brasileira, Brasília, v. 20, n. 4, p. 433-437, 1985. Disponível em:

https://ainfo.cnptia.embrapa.br/digital/bitstream/item/121756/1/15206-67353-1-SM.pdf

VIANA, B. L.; DE MELLO, A. C. L.; LIRA, M. A.; DUBEUX JÚNIOR, J. C. B.; DOS SANTOS, M. V. F.; DA CUNHA, M. V.; FERREIRA, G. D. G. Repetibilidade e respostas de características morfofisiológicas e produtivas de capim-elefante de porte baixo sob pastejo. Pesquisa. Agropecuária Brasileira, Brasília, v. 44, n. 12, p. 1731-1738, 2009. Disponível em: https://dx.doi.org/10.1590/S0100-204X2009001200024

VIANA, A. P.; RESENDE, M. D. V. Genética quantitativa no melhoramento de fruteiras. 1. ed. Rio de Janeiro: Interciência. 2014. 296p. 